\title{
Cost-Effectiveness Analysis Kloramfenikol Dan Seftriakson Untuk Pengobatan Demam Tifoid Pada Pasien Dewasa Di Rumah Sakit Sanglah Denpasar
}

\author{
Amelia Lorensia, Doddy de Queljoe, dan Made Dwike \\ Fakultas Farmasi, Universitas Surabaya \\ Korespondensi: Made Dwike \\ Email:madedwikess@gmail.com
}

Submitted : 21-10-2018, Revised : 28-11-2018, Accepted : 14-12-2018

\begin{abstract}
ABSTRAK: Jumlah pasien demam tifoid di Indonesia masih tinggi. Demam tifoid dapat diobati dengan terapi antibiotik seperti kloramfenikol dan seftriakson. Tujuan dari penelitian ini adalah untuk membandingkan efektivitas biaya kloramfenikol dan seftriakson yang diberikan kepada pasien dewasa yang didiagnosis demam tifoid di Rumah Sakit Sanglah Denpasar. Pada penelitian ini dilakukan perbandingan antara dua alternatif yang ada dengan menggunakan perspektif rumah sakit. Metode retrospektif digunakan untuk mengumpulkan data dari rekam medis pasien, yang didiagnosis dan dirawat inap di Rumah Sakit Sanglah Denpasar selama Januari 2017 hingga Juli 2018. Analisis biaya dilakukan dengan menggunakan metode cost-effectiveness grid dan costeffectiveness ratio (ACER). Cost-effectiveness grid menunjukkan bahwa dominan seftriakson untuk pasien dengan demam tifoid. Analisis ACER untuk seftriakson adalah Rp. 2.097.170,88 dengan efektifitas (lama tinggal) 4,27 hari, dan Rp. 2.097.170,88 dengan efektivitas (waktu mencapai suhu normal) 2,42 hari. Analisis ACER untuk kloramfenikol adalah Rp. 2.555.464,22 dengan efektifitas (lama tinggal) 10,22 hari, dan Rp. 2.555.464,22 dengan efektivitas (waktu mencapai suhu normal) 3,44 hari. Analisis ACER menunjukkan tingkat seftriakson yang lebih rendah dan efektivitas yang lebih tinggi berdasarkan lama tinggal dan waktu mencapai suhu normal. Kesimpulan dari penelitian ini adalah bahwa seftriakson lebih cost-effective daripada kloramfenikol.
\end{abstract}

Kata kunci: analisis efektivitas biaya; demam tifoid; kloramfenikol; seftriakson

\begin{abstract}
The number of typhoid fever patient in Indonesia is still high. Typhoid fever can be treated by antibiotic therapy such as chloramphenicol and ceftriaxone. The purpose of this study was to compare the cost-effectiveness of chloramphenicol and ceftriaxone which were given to adult patients who were diagnosed with typhoid fever in Sanglah Denpasar Hospital. A comparative study between two alternatives was conducted using the hospital perspective. Retrospective method was used to collect data from patient medical records, who was diagnosed and hospitalized in Sanglah Denpasar Hospital during January 2017 until July 2018. The cost analysis was perform using cost-effectiveness grid and cost-effectiveness ratio (ACER) methods. Cost-effectiveness grid showed that dominant of ceftriaxone for patient with typhoid fever. ACER analysis for ceftriaxone was IDR 2,097,170.88 with effectivenes (length of stay) 4.27 days, and was IDR 2,097,170.88 with effectiveness (the time of reaching normal temperature) 2.42 days. ACER analysis for chloramphenicol was IDR2,555,464.22 with effectivenes (length of stay) 10.22 days, and was IDR 2,555,464.22 with effectiveness (the time of reaching normal temperature) 3.44 days. ACER analysis showed lower degree of ceftriaxone and higher effectiveness based on length of stay and the time of reaching normal temperature. It can be concluded that ceftriaxone is more cost-effective than chloramphenicol.
\end{abstract}

Keywords: cost-effectiveness analysis; typhoid fever; chloramphenicol; ceftriaxone 


\section{Pendahuluan}

Kasus demam tifoid dari tahun ke tahun menunjukkan kecenderungan peningkatan, yang berdasarkan penelitian kasus di rumah sakit di Indonesia dengan rata-rata kesakitan penduduk dan kematian sekitar 0,6-5\% [1]. Penyakit terbanyak kedua pada pasien rawat inap di rumah sakit di Indonesia adalah demam tifoid dengan jumlah kasus $81.116(3,15 \%)$ [2].

Hasil Riset Kesehatan Dasar Provinsi Bali pada tahun 2009 menunjukkan bahwa prevalensi penyakit tifoid yang berisiko berada di atas nilai rerata Provinsi Bali yaitu 0,9\%. Prevalensi penyakit tifoid lebih tinggi dibandingkan dengan penyakit menular lainnya seperti prevalensi penyakit tuberculosis berisiko (di atas nilai rerata Provinsi Bali yaitu 0,5\%), prevalensi penyakit campak berisiko (di atas nilai rerata Provinsi Bali yaitu 0,5\%), prevalensi penyakit hepatitis berisiko (di atas nilai rerata Provinsi Bali yaitu 0,3\%), prevalensi penyakit demam berdarah berisiko (di atas nilai rerata Provinsi Bali yaitu 0,3\%) dan prevalensi penyakit malaria yang berisiko (di atas nilai rerata Provinsi Bali yaitu 0,3\%) [3]. Rumah Sakit Umum Pusat (RSUP) Sanglah Denpasar merupakan rumah sakit yang menjadi unggulan di bidang pelayanan, pendidikan, dan penelitian di Bali. Terkait dengan penyakit demam tifoid, angka kejadian pada tahun 2017 di RSUP Sanglah terbilang cukup banyak. Pada tahun 2017, di RSUP Sanglah demam tifoid termasuk dalam 10 besar kasus penyakit yang sering terjadi.

Pemberian antibiotik pada pengobatan demam tifoid diperlukan. Kloramfenikol tergolong antibiotik yang masih diberikan hingga sekarang pada kasus demam tifoid, khususnya di negara berkembang termasuk Indonesia [4]. Kloramfenikol menurut WHO dimasukkan sebagai obat alternatif atau lini kedua karena lini pertamanya adalah fluorokuinolon, khususnya pada demam tifoid dewasa. Namun demikian, hingga saat ini masih banyak kasus demam tifoid di rumah sakit yang menggunakan kloramfenikol sebagai pilihan pertama [5]. Penelitian yang dilakukan di RSUP
Sanglah Denpasar diperoleh data terkait dengan jumlah antibiotik yang paling banyak digunakan yaitu antibiotik tunggal (sebanyak 66,1\%) dan antibiotik tunggal yang paling banyak digunakan tersebut adalah kloramfenikol (sebesar 29,3\%) [6].

Antibiotik yang poten dan efektif untuk pengobatan demam tifoid dalam jangka pendek adalah seftriakson. Keuntungan dari seftriakson ini adalah secara selektif dapat merusak struktur kuman dan tidak mengganggu sel tubuh manusia, mempunyai spektrum luas, penetrasi jaringan cukup baik, resistensi kuman masih terbatas tetapi harga antibiotik ini cukup mahal [7]. Sefalosporin generasi ketiga seperti seftriakson atau sefotaksim diindikasikan pada kasus demam tifoid yang resisten terhadap kloramfenikol. Strain yang resisten pada umumnya rentan terhadap sefalosporin generasi ketiga dan juga untuk beberapa kasus yang resisten terhadap fluorokuinolon, seftriakson dianggap sensitif dan memiliki hasil yang baik jika digunakan sebagai terapi alternatif bersama dengan azitromisin dan sefiksim [8].

Pengobatan utama untuk demam tifoid adalah dengan pemberian antibiotik, tetapi pengobatan yang diberikan oleh pelayanan kesehatan tidak hanya dengan terapi antibiotik. Tata laksana demam tifoid terdiri atas dua terapi, yaitu terapi umum yang bersifat penunjang atau suportif dan terapi khusus dengan pemberian antibiotik [9]. Pada demam tifoid tidak hanya pengobatannya yang terbilang cukup mahal, tetapi apabila pasien menjalani rawat inap maka akan mengeluarkan biaya yang lebih mahal lagi. Rata-rata lama rawat inap yang dianggap efektif pada pasien demam tifoid dengan penggunaan antibiotik yaitu berkisar 4-14 hari, sehingga disinilah pentingnya dilakukan penelitian farmakoekonomi [10]. Analisis biaya dalam farmakoekonomi digunakan untuk melakukan perbandingan efektivitas biaya dari penggunaan alternatif obat pada penyakit tertentu, dengan tujuan untuk mengetahui obat yang lebih cost-effective.

\section{Metode}


Penelitian ini merupakan salah satu evaluasi ekonomi kesehatan yang bersifat observasional dengan melakukan studi perbandingan (comparative study) antara dua alternatif yang ada dengan menggunakan perspektif rumah sakit dan pengambilan data yang dilakukan secara retrospektif pada bulan Januari 2017 sampai dengan Juli 2018. Pada penelitian ini, metode yang digunakan adalah CEA dengan outcome klinis yaitu lama rawat inap dan waktu bebas demam. Data dianalisis menggunakan independent sample $t$ test.

Sampel pada penelitian ini adalah bagian dari populasi yang memenuhi kriteria inklusi dan kriteria eksklusi yang diambil dengan metode total sampling. Besar sampel ditentukan berdasarkan lamanya periode penelitian. Penelitian dilakukan selama bulan April 2018-Juli 2018.

Variabel bebas dalam penelitian ini adalah jenis pengobatan yaitu terapi dengan menggunakan kloramfenikol dan terapi dengan menggunakan seftriakson. Variabel tergantung dalam penelitian ini adalah total biaya (cost) pengobatan dan efektivitas (effectiveness) pengobatan.

Pengumpulan data dilakukan secara retrospektif dengan mengambil data biaya rumah sakit dan data rekam medis pasien demam tifoid di RSUP Sanglah Denpasar yang akan digunakan sebagai sampel penelitian. Analisis data yaitu dengan membandingkan biaya medis langsung dengan efektivitas pengobatan antara setiap kelompok (kelompok kloramfenikol dan kelompok seftriakson) sehingga nantinya diperoleh pengobatan yang cost-effective dengan metode Average Cost-Effectiveness Ratio (ACER).

\section{Hasil dan pembahasan}

\subsection{Data karateristik sampel}

Pada penelitian ini didapatkan 95 subyek penelitian, dimana terdiri dari 59 subyek dengan pengobatan kloramfenikol dan 36 subyek dengan pengobatan seftriakson serta telah sesuai dengan kriteria inklusi dan eksklusi. Data yang dieksklusi adalah pasien demam tifoid dengan penyakit penyerta seperti infeksi pneumonia, hepatitis, perforasi usus, dan perdarahan gastrointestinal.

Karakteristik dasar subyek penelitian dikelompokkan berdasarkan jenis kelamin, usia, tingkat pendidikan, pekerjaan, sistem pembiayaan, dan riwayat penyakit (Tabel 1).

Berdasarkan hasil penelitian, jumlah subyek laki-laki (25 pasien) lebih rendah dibandingkan perempuan (34) untuk kelompok seftriakson, sedangkan pada kelompok kloramfenikol baik subyek laki-laki maupun perempuan jumlahnya sama (18 pasien). Berdasarkan kriteria umur pasien, pada penelitian ini didapatkan bahwa pasien demam tifoid terbanyak pada rentang umur 18-25 tahun dan 26-35 tahun, sedangkan yang paling sedikit pada rentang umur 46-60 tahun baik dari kelompok kloramfenikol maupun seftriakson. Hal ini sesuai dengan penelitian demam tifoid yang dilakukan di Sleman, dimana demam tifoid termasuk salah satu dari sepuluh besar penyakit yang diderita orang dewasa umur 25-44 tahun [11]. Berdasarkan pekerjaan, buruh, petani, dan nelayan cenderung mempunyai resiko demam tifoid sebesar 1,04 kali dibanding kelompok ibu rumah tangga [12]. Hubungan pekerjaan dengan resiko demam tifoid lebih banyak dilihat berdasarkan kemungkinan keterpaparan khusus, derajat keterpaparan, dan resiko menurut antisitasnya. Setiap pekerjaan memiliki resiko yang berbeda, oleh karena itu resiko penyakit juga akan berbeda pula. Berdasarkan tingkat pendidikan terhadap terjadinya demam tifoid, maka dalam penelitian ini dapat dikatakan bahwa semakin tinggi tingkat pendidikan maka seseorang tersebut semakin baik dalam hal menyikapi suatu masalah.

Kepesertaan pasien untuk menjadi anggota Badan Penyelenggara Jaminan Sosial (BPJS) ditentukan oleh pengetahuan tentang informasi mengenai BPJS, disamping itu juga ada faktor personal reference yaitu keinginan sendiri atau 
Tabel 1. Distribusi frekuensi karakteristik subyek penelitian

\begin{tabular}{|c|c|c|c|c|c|c|c|}
\hline \multirow[t]{3}{*}{ Karakteristik } & & \multicolumn{4}{|l|}{ Kelompok } & \multicolumn{2}{|c|}{$\begin{array}{l}\text { Uji perbedaan antar kelom- } \\
\text { pok }\end{array}$} \\
\hline & & \multicolumn{2}{|c|}{ Kloramfenikol } & \multicolumn{2}{|c|}{ Seftriakson } & \multirow[t]{2}{*}{ Nilai P } & \multirow[t]{2}{*}{ Kesimpulan } \\
\hline & & Frekuensi & $\begin{array}{l}\text { Persentase } \\
(\%)\end{array}$ & Frekuensi & $\begin{array}{l}\text { Persentase } \\
(\%)\end{array}$ & & \\
\hline \multirow[t]{2}{*}{ Jenis Kelamin } & Laki-laki & 18 & 50,00 & 25 & 42,37 & \multirow[t]{2}{*}{0,469} & \multirow{2}{*}{$\begin{array}{l}\text { Tidak berbeda } \\
\text { signifikan }\end{array}$} \\
\hline & Perempuan & 18 & 50,00 & 34 & 57,63 & & \\
\hline \multirow[t]{4}{*}{ Usia (Tahun) } & $18-25$ & 15 & 41,67 & 28 & 47,46 & \multirow[t]{4}{*}{0,479} & \multirow{4}{*}{$\begin{array}{l}\text { Tidak berbeda } \\
\text { signifikan }\end{array}$} \\
\hline & $26-35$ & 7 & 19,44 & 16 & 27,12 & & \\
\hline & $36-45$ & 10 & 27,78 & 9 & 15,25 & & \\
\hline & $46-60$ & 4 & 11,11 & 6 & 10,17 & & \\
\hline \multirow{4}{*}{$\begin{array}{l}\text { Tingkat Pen- } \\
\text { didikan }\end{array}$} & Dasar & 0 & 0,00 & 0 & 0,00 & \multirow[t]{4}{*}{0,275} & \multirow{4}{*}{$\begin{array}{l}\text { Tidak berbeda } \\
\text { signifikan }\end{array}$} \\
\hline & Menengah & 0 & 0,00 & 0 & 0,00 & & \\
\hline & Atas & 4 & 11,11 & 3 & 5,08 & & \\
\hline & $\begin{array}{l}\text { Perguruan } \\
\text { Tinggi }\end{array}$ & 32 & 88,89 & 56 & 94,92 & & \\
\hline \multirow[t]{2}{*}{ Pekerjaan } & Bekerja & 23 & 63,89 & 34 & 57,63 & \multirow[t]{2}{*}{0,546} & \multirow{2}{*}{$\begin{array}{l}\text { Tidak berbeda } \\
\text { signifikan }\end{array}$} \\
\hline & $\begin{array}{l}\text { Tidak } \\
\text { bekerja }\end{array}$ & 13 & 36,11 & 25 & 42,37 & & \\
\hline \multirow{2}{*}{$\begin{array}{l}\text { Sistem } \\
\text { Pembiayaan }\end{array}$} & BPJS & 36 & 100,00 & 40 & 67,80 & \multirow[t]{2}{*}{0,000} & \multirow{2}{*}{$\begin{array}{l}\text { Berbeda signifi- } \\
\text { kan }\end{array}$} \\
\hline & Umum & 0 & 0,00 & 19 & 32,20 & & \\
\hline \multirow[t]{6}{*}{$\begin{array}{l}\text { Riwayat Pe- } \\
\text { nyakit; }\end{array}$} & $\begin{array}{l}\text { Diabetes } \\
\text { mellitus }\end{array}$ & 3 & 8,33 & 5 & 8,46 & \multirow[t]{6}{*}{0,880} & \multirow[t]{6}{*}{$\begin{array}{l}\text { Tidak berbeda } \\
\text { signifikan }\end{array}$} \\
\hline & Stroke & 0 & 0,00 & 1 & 1,70 & & \\
\hline & Hipertensi & 4 & 11,11 & 4 & 6,78 & & \\
\hline & Asam urat & 3 & 8,33 & 4 & 6,78 & & \\
\hline & Kolesterol & 0 & 0,00 & 1 & 1,70 & & \\
\hline & Tidak ada & 26 & 72,23 & 44 & 74,58 & & \\
\hline
\end{tabular}

Tabel 2. Total biaya (Direct Medical Cost)

\begin{tabular}{lll}
\hline Biaya medis langsung & Kelompok kloramfenikol & Kelompok seftriakson \\
\hline Antibiotik (Rp.) & $75.474,74$ & $115.056,47$ \\
Pemakaian kamar (Rp.) & $1.726 .666,67$ & $1.145 .169,49$ \\
Laboratorium (Rp.) & $420.222,22$ & $473.021,00$ \\
Tindakan (Rp.) & $311.166,67$ & $341.730,34$ \\
Administrasi (Rp.) & $21.666,67$ & $22.203,00$ \\
Total (Rp.) & $\mathbf{2 . 5 5 5 . 4 6 4 , 2 2}$ & $\mathbf{2 . 0 9 7 . 1 7 0 , 8 8}$ \\
\hline
\end{tabular}

ajakan orang lain untuk menjadi peserta BPJS serta faktor motivasi.

\subsection{Biaya medis langsung}

Biaya dalam penelitian ini menggunakan direct medical cost (biaya medis langsung) yang meliputi penggunaan antibiotik, biaya pemakaian kamar, biaya tindakan, biaya laboratorium, 
dan biaya administrasi. Biaya rata-rata medis langsung pada pasien demam tifoid selama perawatan di rumah sakit yang menggunakan kloramfenikol adalah sebesar Rp. 2.555.464,22/ pasien dan pasien yang menggunakan seftriakson adalah sebesar Rp. 2.097.170,88/pasien (Tabel 2). Dari Tabel 2 dapat dilihat bahwa biaya total pengobatan yang paling tinggi adalah kelompok antibiotik kloramfenikol yaitu Rp. 2.555.464,22. Hal tersebut sejalan dengan penelitian yang dilakukan oleh Yusrizal (2011) yang menyatakan bahwa rata-rata biaya total pengobatan demam tifoid menggunakan kloramfenikol lebih tinggi daripada menggunakan seftriakson [13].

\subsection{Efektivitas pengobatan}

Pada penelitian ini efektivitas pengobatan dinilai berdasarkan perbandingan lama perawatan dan hilangnya demam pada pasien yang menggunakan kloramfenikol dengan pasien yang menggunakan seftriakson. Lama perawatan rata-rata pasienyang menggunakan kloramfenikol dan seftriakson masing-masing adalah 10,22 hari dan 4,27 hari. Rata-rata hilangnya demam pada pasien yang menggunakan kloramfenikol adalah 3,44 hari, sedangkan pasien yang menggunakan seftriakson adalah 2,42 hari.

Hilangnya gejala ikutan yang dialami oleh pasien demam tifoid yang menggunakan antibiotik kloramfenikol rata-rata pada hari ke-5,56 dan pada hari ke-4,22 bagi pasien yang menggunakan antibiotik seftriakson. Gejala ikutan yang dimaksud adalah nyeri perut, keluhan buang air besar, sakit kepala, pusing, nyeri otot, mual, muntah, dan diare. Pada penelitian sebelumnya dikatakan bahwa nyeri perut adalah keluhan yang terdapat pada semua penderita demam tifoid diikuti keluhan buang air besar, demam, sakit kepala, dan perut kembung. Hilangnya keluhan terhadap gejala ikutan kemungkinan akan berbeda pada setiap pasien demam tifoid dengan pemberian antibiotik yang berbeda [14].

\subsection{Interpretasi ACER}

Pada penelitian ini efektivitas biaya dilihat dengan membandingkan biaya yang dikeluarkan dengan outcome pengobatan antara kelompok kloramfenikol dan seftriakson. Nilai Average Cost-Effectiveness Ratio (ACER) kelompok kloramfenikol sebesar Rp. 250.045,42/hari dan kelompok seftriakson sebesar Rp. 491.140,72/ hari untuk lama rawat inap, sedangkan untuk hilangnya demam nilai ACER yang diperoleh sebesar Rp. 742.867,51/hari pada kelompok koramfenikol dan Rp. 866.599,54/hari pada kelompok seftriakson (Tabel 3 dan Tabel 4).

Perhitungan nilai ACER ini digunakan untuk mengetahui biaya per hari yang harus dikeluarkan pasien dibandingkan dengan efektivitasnya. Efektivitas dalam penelitian ini diukur dari rata-rata lama rawat inap dan waktu bebas demam dari masing-masing kelompok terapi. Dari analisis efektivitas biaya diperoleh

Tabel 3. Perhitungan Average Cost-Effectiveness Ratio (ACER) antara total biaya dengan lama rawat inap

\begin{tabular}{llll}
\hline Kelompok obat & Total biaya, Rp. (C) & Lama rawat inap, hari (E) & ACER, Rp./hari (C/E) \\
\hline Kloramfenikol & $2.555 .464,22$ & 10,22 & $250.045,42$ \\
Seftriakson & $2.097 .170,88$ & 4,27 & $491.140,72$ \\
\hline
\end{tabular}

Tabel 4. Perhitungan Average Cost-Effectiveness Ratio (ACER) antara total biaya dengan hilangnya demam

\begin{tabular}{llll}
\hline Kelompok obat & Total biaya, Rp. (C) & Lama rawat inap, hari (E) & ACER, Rp./hari (C/E) \\
\hline Kloramfenikol & $2.555 .464,22$ & 3,44 & $742.867,51$ \\
Seftriakson & $2.097 .170,88$ & 2,42 & $866.599,54$ \\
\hline
\end{tabular}


bahwa kelompok seftriakson lebih cost-effective dibandingkan dengan kelompok kloramfenikol, meskipun biaya harian (ACER) kelompok seftriakson lebih mahal jika dibandingkan dengan kelompok kloramfenikol. Namun demikian, jika dibandingkan dengan efektivitasnya (lama rawat inap dan waktu bebas demam) biaya ini akan berbeda. Kelompok seftriakson lebih efektif dengan lama rawat inap 4,27 hari dengan pengeluaran biaya lebih rendah dibandingkan dengan antibiotik kloramfenikol dengan lama rawat inap 10,22 hari.

Penentuan posisi alternatif pengobatan demam tifoid berdasarkan diagram efektivitas biaya diketahui posisi seftriakson terletak pada kuadran II yang artinya seftriakson memiliki efektivitas tinggi dengan biaya yang rendah dibandingkan dengan kloramfenikol (Tabel 5 dan Gambar 1).

\subsection{Analisis sensitivitas}

Pada Tabel 6 dan Tabel 7 dapat diketahui analisis sensitivitas dari penggunaan kloramfenikol dan seftriakson dengan mengeluarkan biaya pemakaian kamar dan biaya tindakan, dimana biaya tersebut memiliki

Tabel 5. Diagram efektivitas-biaya berdasarkan lama rawat inap dan hilangnya demam

\begin{tabular}{lllll}
\hline & & \multicolumn{2}{c}{ Biaya dari seftriakson terhadap kloramfenikol } \\
\cline { 3 - 5 } & & Lebih rendah & Sama & Lebih tinggi \\
\hline Efektivitas seftriakson & Lebih tinggi & Seftriakson (dominant) & + & + - (trade-off) \\
terhadap kloramfenikol & Sama & + & Arbitary & - \\
& Lebih rendah & + -- (trade-off) & - & - (dominated) \\
\hline
\end{tabular}

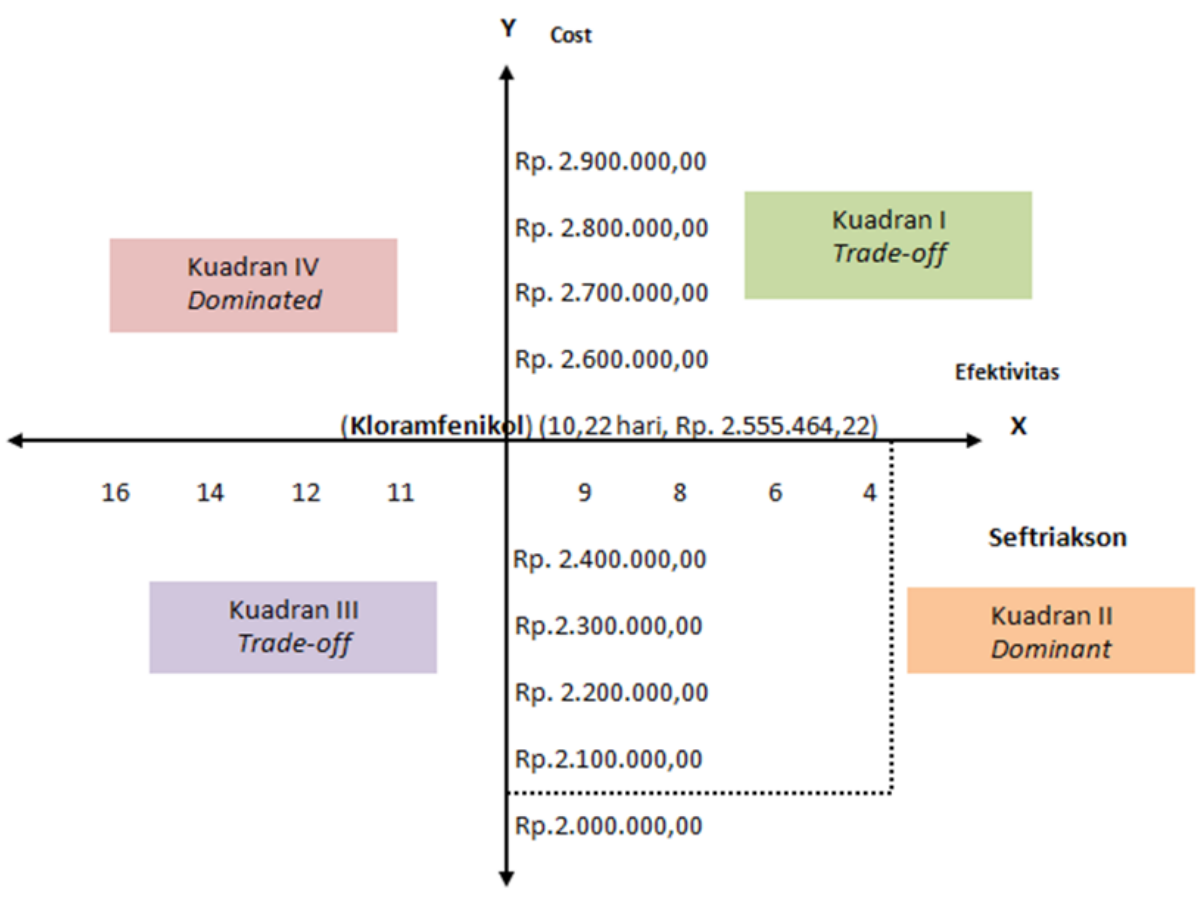

Gambar 1. Cost-Effectiveness plane kloramfenikol dan seftriakson

pengaruh yang cukup besar terhadap penentuan biaya dikarenakan jenis perawatan kelas yang berbeda dan biaya disesuaikan dengan jenis perawatan kelas tersebut.

Hasil analisis sensitivitas menunjukkan nilai ACER dari penggunaan seftriakson tanpa 
Tabel 6. Simulasi terhadap sensitivitas ACER pasien demam tifoid berdasarkan lama rawat inap

\begin{tabular}{llll}
\hline No. & Uraian & \multicolumn{2}{l}{ Kelompok } \\
\cline { 3 - 4 } & & Kloramfenikol & Seftriakson \\
\hline 1. & ACER awal (Rp./hari) & $250.045,42$ & $491.140,72$ \\
2. & ACER tanpa biaya pemakaian kamar (Rp./hari) & $81.095,65$ & $222.951,15$ \\
3. & ACER tanpa biaya tindakan (Rp./hari) & $219.598,59$ & $411.112,54$ \\
4. & ACER tanpa biaya pemakaian kamar dan biaya tindakan (Rp./hari) & $50.417,52$ & $142.922,96$ \\
\hline
\end{tabular}

Tabel 7. Simulasi terhadap sensitivitas ACER pasien demam tifoid berdasarkan hilangnya demam

\begin{tabular}{llll}
\hline \multirow{2}{*}{ No. } & Uraian & \multicolumn{1}{l}{ Kelompok } & \\
\cline { 3 - 4 } & & Kloramfenikol & Seftriakson \\
\hline 1 & ACER awal (Rp./hari) & $742.867,51$ & $866.599,54$ \\
2 & ACER tanpa biaya pemakaian kamar (Rp./hari) & $240.929,52$ & $393.389,00$ \\
3 & ACER tanpa biaya tindakan (Rp./hari) & $652.412,08$ & $725.392,79$ \\
4 & ACER tanpa biaya pemakaian kamar dan biaya tindakan (Rp./hari) & $149.786,95$ & $252.182,25$ \\
\hline
\end{tabular}

melibatkan biaya pemakian kamar dan biaya tindakan yaitu Rp. 252.182,25/hari berdasarkan hilangnya demam, sedangkan nilai ACER dari penggunaan kloramfenikol tanpa melibatkan biaya pemakaian kamar dan biaya tindakan yaitu Rp. 149.786,95/hari, dimana selisih dari biaya simulasi tersebut sebesar Rp. 102.395,30/ hari. Hasil analisis sensitivitas ini dengan adanya selisih biaya tersebut maka para praktisi dapat mempertimbangkan bahwa seftriakson bisa dijadikan salah satu antibiotik alternatif yang digunakan dalam pengobatan demam tifoid.

\section{Kesimpulan}

Cost-effectiveness grid menunjukkan hasil dominant pada kelompok seftriakson untuk pasien dengan pengobatan demam tifoid. Hasil ACER menunjukkan bahwa seftriakson memiliki biaya yang rendah dengan efektivitas yang tinggi berdasarkan lama rawat inap dan hilangnya demam. Hasil analisis menunjukkan terdapat perbedaan signifikan total biaya antara kelompok kloramfenikol dibandingkan dengan kelompok seftriakson dalam pengobatan demam tifoid pada pasien dewasa. Hasil penelitian menunjukkan seftriakson lebih cost-effective dibandingkan dengan kloramfenikol.

\section{Daftar Pustaka}

1. Elisabeth Purba I, Wandra T, Nugrahini N, Nawawi S, Kandun N. Program Pengendalian Demam Tifoid di Indonesia: tantangan dan peluang. Media Penelitian dan Pengembangan Kesehatan. 2016;26(2):99-108.

2. Kementerian Kesehatan RI. Profil kesehatan Indonesia tahun 2013. Jakarta: Kementerian Kesehatan RI; 2014.

3. Badan Penelitian dan Pengembangan Departemen Kesehatan RI. Riset Kesehatan Dasar (Riskesdas) Provinsi Bali; 2007.

4. Hadinegoro SR, Kadim M, Devaera Y, Idris NS, Ambarsari CG. Update Management of Infectious Diseases and Gastrointestinal Disorders. Jakarta: Departemen Ilmu Kesehatan Anak FKUI-RSCM; 2012.

5. WHO. Guidelines for the Management of Typhoid Fever; 2011. 
6. Mahasiwi SA. Pola Penggunana Antibiotika pada Pasien Demam Tifoid Rawat Inap Anak di Rumah Sakit Umum Pusat Sanglah Denpasar Tahun 2006. Skripsi. Surabaya: Universitas Surabaya; 2007.

7. Cita YP. Bakteri Salmonella typhi dan demam tifoid. Jurnal Kesehatan Masyarakat Andalas. 2011;6(1):42-6.

8. Karunakaran R, Tay ST, Rahim FF, Lim BB, Sam IC, Kahar-Bador M, Hassan H, Puthucheary SD. Ceftriaxone resistance and genes encoding extended-spectrum $\beta$-lactamase among nontyphoidal Salmonella species from a tertiary care hospital in Kuala Lumpur, Malaysia. Japanese journal of infectious diseases. 2012;65(5):433-5.

9. Nuraini FA, Garna H, Respati P. Perbandingan Kloramfenikol dengan Seftriakson terhadap lama hari turun demam pada anak demam tifoid. Prosiding Pendidikan Dokter. 2015:914-9.
10. Rosinta L. Hubungan Durasi Demam Dengan Kadar Leukosit Pada Penderita Demam Tifoid Anak Usia 5-10 Tahun Yang Dirawat Inap Di Rumah SakitAl-Ihsan Periode Januari-Desember; 2014.

11. Rustam MZ. Hubungan Karakteristik Penderita dengan Kejadian demam Tifoid pada pasien rawat inap di RSUD Salewangan Maros. STRADA Jurnal Ilmiah Kesehatan. 2012;1(2):57-62.

12. Raflizar R, Herawati MH. Hubungan faktor determinan dengan kejadian tifoid di pulau Jawa. Jurnal Ekologi Kesehatan. 2010;9(4):1357-65.

13. Yusrizal. Analisis Efektivitas Biaya Kloramfenikol Dan Seftriakson Pada Pengobatan Pasien Demam Tifoid di Instalasi Rawat Inap RSUD. Abdul Moeloek Tahun 2011. Jurnal Analis Kesehatan. 2013;2(1):227-42.

14. Setiyohadi B, Sumariyono IY, Isbagio H, Kalim H. Buku Ajar Ilmu Penyakit Dalam Edisi V. Jakarta: Interna Publ.; 2009. 